\title{
Lecturers' Perceptions of Leadership Traits which Promote Motivation in a South African Technical and Vocational, Education and Training (TVET) College
}

\author{
Alois Nzembe \\ Masters in Education Student, University of KwaZulu-Natal, South Africa \\ Lecturer, Education and Development, South African TVET College
}

Doi: 10.1515/ajis-2017-0006

\begin{abstract}
Educator morale has been a focus of educational leaders and managers throughout the world, because without educator motivation and morale the learning and teaching in our schools would be grossly compromised. It is against this background that this research was carried out to find out lecturers' perceptions of leadership traits which promote motivation in a Technical and Vocational Education and Training (TVET) college in South Africa. The research questions which guided this research were as follows: What are lecturers' perceptions of leadership traits which promote motivation in an educational and training institution in South Africa? How can educational leaders and management in South Africa integrate their experiences and practices with what educators believe are the main drivers of high lecturer morale? A qualitative study was used to generate data that would be useful in answering the research questions. The nature of this qualitative study required in-depth interviews with participants where qualitative data was generated and interpreted. The researcher saw it fit to use in-depth interviews because this method of data generation would enable the researcher to capture the perspectives, views and opinions of participants about leadership traits which facilitate motivation in the South African TVET College in particular and the South African education system in general. The views of the participants showed that leadership traits such as accountability, responsibility, empathy, decisiveness, assertiveness, charisma, pro-activeness, motivation and communication are the life-blood, foundation and bed-rock of effective leadership and management in the TVET College.
\end{abstract}

Keywords: perception, leadership traits, motivation, lecturers, educators

\section{Introduction}

Technical and Vocational Education and Training (TVET) colleges were introduced by the South African government as a way of addressing the skills gap currently obtaining in South Africa. While the introduction of TVET colleges was a noble idea, The Business Day dated 15 August 2014 reports that White, Colored and Indian youths have overtaken their Black African counterparts in acquiring skills in the past twenty years, despite a number of government interventions aimed at advancing Blacks.

While TVET colleges have tried to develop skills among Black youths, they have been faced with challenges which range from service delivery to basic management principles. One of the management principles which remain a thorn in the operations of TVET college leadership and management is motivation of staff who, coincidentally is ill-equipped, inexperienced and faced with a mammoth task to push the TVET agenda forward. It is against this background that an investigation of lecturers' perceptions of leadership traits which promote motivation in a TVET college in a South African TVET College was carried out. 


\section{Survey of Related Literature}

Zaccaro, Kemp and Bader (2004) define trait leadership as integrated patterns of personal features that mirror an assortment of specific differences and nurture stable leader success across a variety of group and managerial situations. This implies that leadership traits can contribute to the leader's ability to adapt to professional challenges which are prominent within the work environment. Bates (2004) asserts that a leader has to possess affection and information and then has to use this combined desire to be able to motivate staff. Triphathi (2004) revealed that educators' perceptions of the leader's level of care for them have meaningful effects on their performance and behavior. By implication, leaders who are willing to reach out to educators may provide a source of motivation for the educators.

Johns (2006) observes that the main significance of wit at work lies in its ability to kindle, demonstrate, inspire and sooth tensions. This means educators want to see leaders who behave as real human beings. According to Alveraz (2000) a warm, unpretentious sense of humour can divulge humanness, a safe attitude with themselves as leaders. Humour, therefore, may help to remove a tense work environment and create a free environment where educators can flourish and produce the expected outcomes. The leader should afford laughter and also cracks jokes so as to keep the work environment free of tensions (Nyanga 2012). Education leaders should be lighthearted, natural, relaxed, control a little and break the work routine occasionally. Leaders need to foster an informal climate, become conversational and interactive. It is the intention of this research to find out if research that has been carried out in other parts of the world dovetails with educators' perceptions of leadership traits which promote motivation at a South African TVET college. The findings of this research will provide a broad-based foundation for further research in the area of educators' perceptions of leadership traits which promote motivation and morale in South African TVET colleges.

From the researcher's point of view a leader with high expectations keeps the educators with the motivation to perform set tasks. This implies that educational leaders who push educators to achieve expected outcomes at required standards are effective staff motivators. Leaders should not therefore, tolerate failure but set standards and targets for educators to achieve expected results. Most competent leaders use Drucker's (1954) cited in Starbuck (2012) management by objectives (MBO) to motivate their subordinates to produce the expected results. By setting intentions for educators, an educational leader can arouse the interest of educators to perform their duties effectively and efficiently. Most importantly, leaders should communicate their expectations to subordinates because lack of communication is definitely not a technical but a social problem. Unless communications are established for the purpose of work in a professional community, it would not be able to function or even survive (Starbuck 2012 p. 66).

Vasquez (2008) notes that, if high anticipations are transferred to educators through different types of prompts, verbal and non-verbal, educators' performance can be positively influenced. For example, an expectation can be set by the leader through hard work where the leader leads by taking on the lead, in demonstrating effective teaching methods in the classroom. Glasser (1989) cited in Funder (2010) comments that most educators often work harder in a job because they have been given a measurement for quality work. This means that a primary requisite to a solid, motivational routine is an identifiable standard for quality work. When quality is explained to and attained by educators they will work hard to maintain it (Gibson 2000, Farrant 2001).

Research by Vasquez (2008) reveals that educators' perceptions of the leader's level of care for them have meaningful effects on their performance and behavior. These findings are also corroborated by Nyanga (2012) who observes that educators appreciate a leader who acknowledges the contribution they make to the organization by assisting them during times of need. This means that TVET leaders who are willing to reach out to educators and provide the needed assistance in practical ways are likely to inspire and motivate the educators to accomplish educational goals. The leader should always give credit where it is due and give praise and acknowledgement for success to high achievers and also find diplomatic ways of keeping low achievers motivated (Tripathi 2004). This implies that a TVET leader should have the ability to apply reinforcement schedules appropriately and accordingly. Seidenfield (2014) is of the opinion 
that reinforcement schedules can be used effectively to motivate lecturers. He suggests that TVET leaders should use positive reinforcement in a manner which benefits both the students and lecturers. For example, when a TVET leader praises a lecturer for doing a good job, he/she increases the likelihood of the lecturer doing that job very well again. Positive reinforcement both shapes behavior and enhances a lecturer's self-image (Ibid).

Seidenfield (2014) is of the view that positive reinforcement firstly, clearly defines and communicates expected behaviours and strengthens the connection between high performance and rewards. It reinforces a lecturer's behavior immediately after learning a new technique and promotes quick, thorough learning. It motivates effective lecturers to continue to perform good work. It increases productivity by rewarding lecturers who conserve time and resources. Lecturers who are rewarded after they successfully perform feel self-confident and become eager to learn new techniques, take advanced training, and accept more responsibility. Rewarding lecturers who suggest improved work procedures will produce more innovation, that is, if the leadership create a relaxed work environment, reward new ideas and tolerate innovative failures.

\section{Research Design and Methodology}

Macmillan and Schumacher (2006 p. 31 define a research design as "a plan and structure of the investigation used to obtain evidence to answer research questions". The research design which was used for this study was a qualitative research design. Qualitative research design focus on discovering and understanding the experiences, perceptions and thoughts of the participants, that is, qualitative research explores meaning, purpose or reality (lbid). In other words, qualitative research design is a situated activity that locates the observer in the world. They turn the world into a series of representations, including fields-notes, interviews, conversations, photographs, recordings and memos to the self. At this level, qualitative research design involves an interpretive, naturalistic approach to the world. This means that qualitative researchers study human phenomenon in its natural settings, attempting to make sense of, or interpret phenomenon in terms of the meanings people bring to them (Denzin and Lincoln 2005).

\subsection{Research Paradigm}

A research paradigm is a particular perspective which defines what is acceptable to research and how the research will be carried out (Berg and Theron 2003). For the purposes of this study an interpretive research paradigm was be used. According to Cohen, Manion and Morrison (2011) in the interpretive research perspective the researcher needs to engage the situation from the point of view of the participants. For example, in this study, the research tried to understand lecturers' perceptions on leadership traits which promote motivation in the TVET College by probing lecturers' attitudes and beliefs towards certain leadership traits through the eyes and cognitive lenses of the lecturers. However, this could not be done without ignoring the larger social, cultural and political contexts, as the interpretivist approach to research is underpinned by the idea that people's behavior is context-dependent (Cohen, Manion and Morrison 2011).

\subsection{The Research Sample}

A sample is group on which information is obtained (Fraenkel and Wallen (2008). In this study a purposive research sample was used because the researcher did not intend to generalize the research findings beyond the group sampled. To this end the researcher selected six educators who participated in a semi-structured interview. Patton (2002) is of the view that in purposive sampling subjects are selected because of some characteristics. In this study the researcher deliberately selected a specific group of participants because this group was likely to provide information which would be relevant to the research questions and objectives. For ethical reasons the real names of the participants were not used and also the South African TVET College was also not identified by its actual name. 


\section{Presentation and Discussion of Findings}

This section presents, presents analyses and interprets the data which the researcher generated mainly through interviewing six educators at a TVET College in Northern KwaZulu-Natal, South Africa. The researcher used interviews only to generate data because from the researcher' point of view this data generation instrument was the most appropriate in eliciting lecturers' perceptions of leadership traits which boost morale in the TVET college. To this end an interview schedule of eight questions was used to generate data about educators' perceptions of leadership traits which promote motivation in a South African TVET College. The process of triangulation was done through drawing differences and similarities between views from the participants. This implies that the researcher tried to make comparisons of participants' perceptions of leadership traits which promote motivation in a South African TVET College and attempt to deduce if they are similar or different responses from the participants.

\subsection{Leadership traits practiced at the college}

The findings obtained from participants were both positive and negative. Some participants were of the view that college management was accountable, empathetic and passionate about its managerial responsibilities while others were of the view that the leadership and management of the TVET College was autocratic. For example Miss Hlela was of the view that:

The leadership and management of the TVET College has a high level of accountability because it follows up on educators and monitor the effectiveness of policies and procedures at the college.

This view was also supported by Mrs Naidoo who said:

The college management shows accountability and responsibility because they follow up on assessment due dates, submission of students' marks from lecturers. The senior lecturers also monitor junior lecturers' portfolios of assessment to see to it that work is generally up-to-date. Senior lecturers also provide feedback to junior lecturers immediately.

Mr. Macu was also positive about the leadership traits of managers in the TVET College under study. He had this to say:

Our leaders and managers have a passion in the vision of the college. They communicate regularly with staff members about issues affecting the college staff and students. For example, we are kept updated about such issues as staff performance and evaluation.

The above sentiments were also supported by Mr. Ngema who noted that the leadership and management of the college is:

Empathetic when educators encounter problems such as illness and death in the family. For example, when educators experience death in the family management pay condolences and give educators time-off to go and bury their loved ones.

While the above participants had a positive view of leadership qualities exercised at the college, the other two had some reservations on the leadership styles exhibited by the college leadership and management. For example, Mr. Rajneeth was of the view that the leadership and management of the TVET College under study exercised:

Autocratic leadership style because at most, you would find that you can raise concerns and proposed solutions only to find that your solutions are never implemented.

This view was also supported by Mr. Ximba who commented that the leadership and management of the college under study exercised:

Autocratic management styles because lecturers are on the receiving end of information from management. Educators' concerns are not acted upon. 
From my experience working in the education sector I have discovered that the majority of the views expressed by the respondents are a true reflection of educational managers in general and leaders in the South African TVET sector in particular. My analysis of leadership traits which promote motivation in the South African TVET sector have revealed that in the majority of situations leaders and managers in the South African TVET sector are accommodative of educators' challenges inside and outside of the workplace. The views from the above respondents revealed that the leadership and management in the South African TVET sector can exhibit traits such as responsibility, accountability, empathy and a passion for the accomplishment of short-term, medium-term, long-term goals, mission and vision of the South African TVET sector. South African TVET leadership and management ensure the achievement of goals by keeping educators informed about important developments in the sector. When lecturers encounter problems, be they social, professional or financial, the leadership tries to assist in the best way possible. The sentiments of the respondents in this study show a positive view of leadership traits which promote motivation in the South African TVET sector because according to Tripathi (2004) leaders' level of care for their subordinates have meaningful effects on the followers' performance and behavior. This view is corroborated by Bates (2004) who is of the view that a leader has to possess love and knowledge and then has to use this combined passion to be able to motivate staff.

While authoritarianism has emerged in this research as one of the negative leadership trait exhibited by leaders and managers in the South African TVET system, it can be argued that leaders may not be successful in the accomplishment of the college goals if they are not assertive and be in a position to make unpopular decisions. They are benefits to the institution when leaders are assertive because according to Graham (2014) assertiveness helps to eliminate the confusing and inconsistent messages many leaders often convey unintentionally to their subordinates and coworkers.

One other aspect of leadership and management which emerges in the data gleaned from the above respondents is that different situations require different leadership approaches. It may not be pragmatic to apply participative leadership styles when the situation requires the manager or leader to adopt a radical, assertive and decisive approach to the problem at hand. Northouse (2004) highlights the view that the basic premise of the situational theory is that different situations demand different kinds of leadership. By implication it means that any leader worthy his/her salt should be in a position to read between the lines and apply a leadership style which best addresses the prevailing problem.

\subsection{Leadership Traits Which Promote Motivation}

The participants came up with a variety of responses regarding leadership traits which promote motivation. For example, Miss Hlela was of the opinion that accountability is a cornerstone of good leadership and management. She had this to say:

The institution should be accountable.......accountability can avoid blaming each other when things go wrong.

Mrs. Naidoo was of the view that decisiveness can help the college to move forward and realize its goals. She said,

Our leaders should be decisive. On a number of occasions our institution happens to be plagued by disruptions by students. Sometimes it takes a long time to come up with a solution which indicates a lack of decisiveness on the part of our leaders.

Mr. Macu thought that a leader should have team-building skills. He had this to say, "leaders should work together with staff and other stakeholders in improving teaching and learning".

Mr. Rajneeth was of the view that developing a system of checks and balances was an important quality of an effective leader. He said,

We need leaders who will prioritize, check on their personnel, take pride in what they do, monitor and apply policies and procedures fairly, follow-up on outstanding issues and help educators in what they do. 
Mr. Ximba thought that a leader should be able and willing to delegate responsibilities. He commented that,

Managers should delegate responsibilities to subject committees headed by Senior Lecturers or Heads of Departments. Currently they are no Senior Lecturers or Head of Departments per subject. This compromises quality teaching and learning.

Mrs. Ngema viewed accountability as a trait which is defines effective and efficient leadership. She was of the opinion that,

I believe that accountability can promote lecturers to be more responsible in their work. If management follow-up on all outstanding issues, monitor lecturers' work and hold any lecturer accountable for work not done, lecturers would be more responsible and motivated to do their work.

The above responses show that educators expect to work with leaders and managers who are accountable, decisive, team-builders and also those who are able to delegate responsibilities. These findings tally with Gardner (1989) cited in Fleenor (2011 p. 831) who concludes that traits such as,

\begin{abstract}
Action-oriented judgement, eagerness to accept responsibility, task-competency, understanding of followers and their needs, skill in dealing with people, need for achievement, capacity to motivate people, courage and conflict resolution skills, trustworthiness, decisiveness, self-discipline, selfconfidence, assertiveness and adaptability, are important for successful leadership.
\end{abstract}

An examination of the above leadership traits seem to show that leaders who are charismatic may be able to influence lecturers to effectively execute their duties because according to House and Aditya (2003) charismatic leaders have very strong convictions in the moral correctness of their beliefs. This means that in the contemporary educational context where curriculum transformation and managerial practices are changing at lightning speed, the need for charismatic leaders can never be over-emphasized.

\title{
4.3 Integrating Leadership Styles and Management Experiences
}

The responses from participants on this theme generally agreed that communicating with both lecturers and students can go a long way in addressing some of the challenges the college has been facing for a couple of years.

For example, Mrs. Ngema commented that,

The college leadership should open communication channels on the goals, objectives and mission of the college so that lecturers are motivated to achieve the goals of the college.

Mrs Naidoo concurred by saying,

Leaders must have regular meetings with educators, where they openly discuss problems encountered during the week and also brainstorm on how these problems can be solved.

The college leadership should communicate with lecturers because according to Mrs. Macu,

Leaders have not been able to integrate their experiences to promote lecturer morale because the college experience strikes by both lecturers and students almost every year.

From the above views it can be deduced that most of the challenges the college faces year in and year out emanate from lack of effective communication between the college management, lecturers and students. This implies that an organization which does not have water-tight mechanism for communicating with the different constituencies in its structures is likely to be overwhelmed with problems because when information is passed informally from one member of the organization to the other this can create distortions which will lead to misunderstandings, 
confrontations and confusion between the leadership and staff. Nelson, Raj and Rao (2006) comment that informing employees of the specific goal in mind, making sure they understand it and keeping focused on the goal is the key to the process.

From the preceding analysis it can be argued that communication is the bed-rock and lifeblood of effective organizations. If leaders in the South African TVET College can adopt communication strategies which focus on sending accurate information to both lecturers and students, this can go a long way in reducing some of the challenges the institution is currently facing. When communication is regular and accurate lecturers as well as students will be motivated to play their roles effectively. Communication can also help the TVET leaders transform their institutions because according to Northouse (2004) transformational leadership theory is a process that changes and transforms individuals. It is concerned with emotions, values, ethics, standards, and long-term goals, and includes assessing followers' motives, satisfying their needs and treating them as full human beings. This implies that if the leadership in the South African TVET college strives towards integrating its past experiences and practices, it will be able to transform the way the TVET College is run and also motivate lecturers to accomplish the goals of the TVET College within the context of changing social, economic, political, academic and professional environment.

\subsection{How the College Leadership can Promote Motivation in the Institution}

The responses from the participants seemed to agree that motivation plays an important role among staff in the college. For instance, Mrs Naidoo, a lecturer at the TVET College had this to say,

The TVET College leadership should encourage lecturers to further their studies because staff development plays an important role in grooming lecturers for future leadership and academic responsibilities.

This view was corroborated by Mrs. Ngema who said,

Leaders should consider financial and non-financial motivators. Since money is the greatest motivator, increments should be above the inflation rate. Non-financial motivators such as praising lecturers, staff development, horizontal and vertical job enrichment, and recognizing superior performance by educators is also important.

One way of promoting motivation in the South African TVET College was suggested by Mr. Macu, a college lecturer at the TVET College who commented that, "leaders should recognize and acknowledge duties well-done". This view was supported by Miss Hlela, another lecturer at the TVET College, who said, "lecturers may be more motivated in their jobs if they are praised and good work is recognized and highlighted".

The importance of motivation in the workplaces in general and education training institutions in particular is emphasized by Seidenfield (2014) who is of the view that lecturers who are rewarded after successfully perform feel self-confident and become eager to learn new techniques, take advanced training and accept more responsibility. Rewarding lecturers who suggest improved work procedures will produce more innovation, that is, if you create a relaxed work environment, reward new ideas and tolerate innovative failures. Thus lecturers who receives recognition for their achievements are more likely to be enthusiastic about their work, more cooperative and open to change. Seidenfield (2014) concludes that when leadership of an educational institution show appreciation and reward lecturers for good work, this has a ripple-effect of increasing the lecturers' job commitment and organizational loyalty. This implies that the application of financial and nonfinancial rewards can go a long way in motivating lecturers to work effectively to accomplish the goals of the institution.

The responses elicited from the above participants unreservedly emphasize the importance of motivation in the workplace. Berg and Theron (2003) also highlight the importance of Herzberg's hygiene theory in promoting job satisfaction. They note that factors such as job content, responsibility, achievement, recognition and professional growth can be incorporated into an 
institution's motivation programme to achieve pre-determined goals. It is, therefore, important for the leadership in the South African TVET College to develop and implement a recognition policy for lecturers so that those who perform their duties successfully are rewarded accordingly. Robbins (2009) also notes that Herzberg's theory may be seen as providing an impetus for designing jobs vertically that is, expanding jobs to provide lecturers with more individual responsibility in planning and controlling their work.

\subsection{The Correlation between Leadership traits and Motivation}

The majority of the participants indicated that there is a high correlation between certain leadership styles and a high/low level of motivation among educators. For example, one of the respondents, Mrs. Ngema commented that,

Autocratic styles of leadership create docile subordinates who will lose the mission of the college and work for nothing else besides money. Such subordinates are not worried to go an extra mile to produce better results.

This perceptive was supported by Mrs. Naidoo who said,

Leaders who are high-headed tend to neglect their core-responsibilities thus promoting insubordination. If educators are in-disciplined the institution will run amok thus failing on its core mandate.

Mr. Ximba another respondent was of the opinion that,

If the leadership and management show less optimism, lecturers will also lose hope and be less motivated. If management is less inspired, staff becomes uninspired as well.

Mr. Rajneeth, a lecturer at the South African TVET College summarized the above views by saying, 'if management is motivated to accomplish the mission of the college, it will also increase the morale of lecturers". These views seem to suggest that there is a positive relationship between highly motivated leadership of an educational institution and lecturer morale. If the leadership is motivated and is also able to motivate staff, there is a high probability that staff will also be motivated. However, if the leadership is not less motivated, this can have a domino-effect on educator morale. Buble, Juras and Matic (2014 p. 162) argue that "leadership and motivation are in constant interaction......the most motivated followers have the most motivated leadership and vice versa". Storseth (2004) has also found out that the leadership style that was people-oriented was key predictor for work motivation. These views are also corroborated by Berg and Theron (2003) who argue that humanistic theories are based on the assumption that people are intrinsically good and if given a conducive environment they can show insatiable quest to achieve. Thus, in the work environment it is important for leaders to have a positive attitude towards subordinates so that motivation levels may improve throughout the rank and file of the college staff. This means that a motivated leadership has a positive motivational effect on lecturers.

\subsection{The relationship between staff development and motivation}

On the question which focused on the relationship between staff development and motivation, the majority of respondents indicated that there were no effective staff development programmes at the TVET College. For example, Miss Hlela said,

Yes, they are but they are not enough. There are facilitator, moderator and assessor programmes but not programmes that teach educators how to teach.

Mr. Rajneeth concurred thus,

None, educators are not subjected to any training to develop their skills, not even team building to boost their morale. 
Mrs. Ngema also agreed with the above views and she had this to say,

Management and leadership of the college impose staff development programmes that one has to do, not one wants to do.

Mr. Macu was of a similar view and he said,

They are no staff development programmes that have been implemented. Funding for staff development programmes for educators who wanted to study for the National Professional Diploma in Education (NPDE) and Post Graduate Certificate in Education (PGCE) had challenges of their own.

The above responses show that the lecturers at the South African TVET College rarely undertake college-sponsored staff development programmes which are aligned to their core responsibilities. A lack of relevant staff development programmes may be a major de-motivator among teaching staff at this South African TVET College. Schultz and Balgraim (2003) highlight the fact that staff in the South African education system are exposed to demotivating factors such as unfair and inequitable remuneration system, ineffective training and skills development programmes, an improper reward and recognition system and a lack of employee growth prospects. It therefore, stands to reason that exposing lecturers to staff development programmes is an important ingredient to lecturers' professional growth and development. This is important because supporting lecturers' professional growth and development through tailor-made staff development programmes helps the lecturers to realize their potential, strengths and weaknesses. Berg and Theron (2003) encapsulate the importance of staff development by saying that Maslow's theory of needs emphasize that employees who are exposed to staff development programmes self-actualize and realize their potential. Self-actualization indicates optimal functioning, a rewarding state of the individual's mind through optimal adjustment and growth.

\subsection{How the leadership can promote efficiency in the workplace}

The responses which were obtained from participants emphasized the need for effective communication between the college leadership and educators. For example, Miss Hlela had this to say,

The college leadership has to communicate with educators and students on a regular basis. This will help them to deal with issues just when they are still surfacing.

Another participant, Mrs. Naidoo also gave a similar thought by saying,

The college leadership should adopt a proactive approach to issues pertaining to staff appointments, motivation of educators and students, ordering of study materials and regular communication with both staff and students.

The above views were summarized by Mr. Rajneeth who said,

The college leadership should work hand in glove with educators, follow-up on issues concerned with the growth of the organization and consult with them where possible.

From the above views it can be deduced that communication is one of the most important leadership trait which should be implemented by the top hierarchy of the South African TVET College. Absence of communication in the institution may be the major cause of conflict between the leadership and the lecturers. The fact that the South African TVET College has been experiencing strikes by both educators and students in the past four years is a deep-seated symptom of much deeper challenges which can be addressed through an open system of communication. The college leadership should, therefore, engage lecturers and students more often so that challenges lecturers and students are proactively attended to because according to 
Starbuck (2012 p. 66),

Leaders should communicate their expectations to subordinates because lack of communication is definitely not a technical but a social problem. Unless communication channels are established for the purpose of work in a professional community, it will not be able to function or even survive.

\subsection{The importance communication in motivating staff}

The majority of respondents indicated that there is poor communication in the South African TVET College. One of the respondents, Miss Hlela commented that,

The college leadership does not promote communication and as a result there is always misunderstandings and confrontations between the leadership and staff members as well as students.

This view was supported by Mr. Rajneth who said,

Communication is not effective because from 2012 we have encountered a number of strikes from students as a way of demonstrating their dissatisfaction on the quality of leadership we have at the college.

Because of a lack of communication in the institution Mrs. Naidoo suggested that,

Management should meet with students on a regular basis so that students do not pick up information from the grapevine. Picking up information from the grapevine may cause students to act on unreliable information which may also have detrimental consequences to the smooth running of the college.

The above views all agree that there have been strikes in the TVET College in the past four years.. According to the views of the respondents who took part in the in-depth interviews, the college leadership, educators and students have been involved in conflicts which manifested themselves in the form of strikes by lecturers and students because of a lack of communication. This implies that these strikes could have been avoided if the college leadership had initiated communication mechanisms which aimed at addressing lecturers' and students concerns. Vasquez (2008) notes that if high expectations are communicated to workers through different types of cues: verbal, and non-verbal, the employees' performance can be positively influenced.

\section{Recommendations}

Based on the findings discussed in the preceding section it is recommended that:

- The leadership in the South African TVET College should be more democratic in dealing with staff and student issues. There is need for the leadership to consult widely on issues affecting the smooth running of the college so that it gets as much input from lecturers and students as possible.

- Furthermore, the leadership should delegate responsibilities to subject committees to enhance curriculum delivery. Delegating curriculum responsibilities to subject committees enhances teaching and learning because if subject specialists are involved in designing, planning, implementing and evaluating curriculum issues, this will have a positive impact on students' graduation and certification rates in the college.

- In addition the college leadership should evaluate their experiences so that they are able to deal proactively with current and future challenges. The college leadership of the South African TVET should make a self-introspection and reflect on its past experiences and challenges so that it is able to deal with recurring problems. Being able to deal with recurring problems shows the TVET College is a learning organization.

- Furthermore, the leadership of the South African TVET College should use a variety of motivational techniques so that they appeal to all educators. Motivational techniques such 
as recognition of superior performance and monitory rewards should be incorporated into the college human resource utilization policy so that the majority of lecturers are motivated to accomplish the goals of the TVET system.

- The leadership should focus more on staff development programmes which enhance educators' classroom pedagogical skills. Staff development programmes such as PGCE, NPDE, Honours and Masters degrees, even up to PHDs should be sponsored by the college to encourage young lecturers to acquire higher level qualifications to enhance teaching and learning.

- The leadership should design communication approaches so that crucial information is relayed to students and staff accurately. This can be done by the members of the CMT, including the Campus Managers as well as the Rector of the college. The leadership should also meet with students, at least once a week, and with educators, at least twice a week.

\section{Conclusion}

The study sought to elicit TVET college educators' perceptions of leadership traits which promote motivation among lecturers in a South African TVET college. The research found out that leadership traits such as assertiveness, empathy, pro-activeness, effective team-building skills, communication, decisiveness, pro-activeness, accountability, and responsibility are cornerstones of motivating lecturers in the South African TVET College. It is, therefore, important for the leadership in the TVET College to incorporate these traits in management development programmes so that the mission and vision of the TVET College can be accomplished. The literature reviewed in this study showed that leaders who are caring, decisive, pro-active, accountable, and responsible with superior communication skills and a good sense of humour tend to perform better in their leadership responsibilities.

\section{References}

Alveraz, D. S. (2002). Professional Growth Seminars Encourage Decision-making. NASSP Bulletin: 1 (1) 70-75. Bates, A. (2004). Personnel Management in Zimbabwe. Harare: Howard Dean and Company.

Berg, Z. C. and Theron, A. L. (2003). Psychology in the workplace. Cape Town: Oxford University Press.

Buble, M. Juras, A. and Matic, I. (2014). The relationship between Managers' leadership Styles and Motivation. Management: 19 (1) 162-193.

Cohen, L. Manion, L. and Morrison, K. (2011). Research Methods in Education. Abingdon: Routledge.

Denzin, N. K. and Lincoln, Y. S. (2005). The Sage Handbook of Qualitative Research. Thousand Oaks: Sage.

Farrant, J. S. (2001). Principles and Practice in Education. Essex: Longman.

Fleenor, J. W. (2006). Personnel Psychology. North Carolina: Blackwell Publishers.

Fraenkel, J. R. and Wallen, N. E. (2008). Research How to Design and Evaluate in Education. New York: Mcgrall-Hill.

Funder, D. C. (2010). The Personality Puzzle. London: Norton and Company.

Gibson, J. T. (2000). Psychology and the classroom. New Jersey: Englewood Cliffs.

House, R. J. and Aditya, R. N. (2003). Cross-cultural research on organizational leadership: A critical analysis and a proposed theory. San Francisco: Jossey-Bass.

Johns, G, (2006). Organizational behavior: Understanding and Managing Life at Work. New York: Harper Collins Publishers.

MacMillan, J. H. and Schumacher, S. (2006). Research in Education: A conceptual introduction. New York: Harper and Collins.

Northouse, P. (2004). Leadership: Theory and Practice. Thousand Oaks; Sage Publications.

Nyanga, T. (2012). Small to Medium Enterprises Employees' on the Leader's Traits that Promote Effective Employee Motivation in Zimbabwe. International Journal of Scientific and Technology Research: 2 (2) 5558.

Patton, M. Q. (2002). Qualitative Research and Evaluation Methods. New Jersey: Prentice Hall.

Robbins, S, P. (2009). Organizational Behaviour. Cape Town: Pearson Education.

Schultz, H. and Balgraim, J. (2003). Organizational Behaviour: A Contemporary South African Perspective. Pretoria: Van Sheik.

Seidenfield, M. (2014). How to motivate people in the workplace. 
http://www.inc.com/ss/7-unusual-ways-motivate-employees\#0

Starbuck, K. (2012). The practice of management. Ohio: Blackwell Publishers.

Storseth, F. (2004). Maintaining work motivation during organizational change. International Journal of Human Resource Development Management: 4 (3) 267-287.

Tripathi, P. C. (2004). Personnel Management and Industrial Relations. New Delphi: Sulton.

Vasquez, J. A. (2008). Contexts of Learning of Minority Students. Educational Forum: 52 (4) $243-253$.

Zaccaro, S. J. Kemp, C. and Bader, P. (2004). Leader traits and attributes: The nature of leadership. Thousand Oaks: Sage Publications. 